http://dx.doi.org/10.12775/szhf.2020.012

\author{
LUdMILA E. KRYSHTOP \\ Peoples' Friendship University of Russia: Moscow, Russian Federation \\ E-MAIL: RICPATRIC@GMAIL.COM \\ ORCID: 0000-0002-1012-5953
}

\title{
Morality as the Destiny of Human Being in the Philosophy of Kant and in the Age of German Enlightenment
}

Kant's anthropology is still not a very popular topic in studies on the history of philosophy. Despite the fact that Kant gave a special lecture course on anthropology, published under the title Anthropology from a pragmatic point of view back in the beginning of the $19^{\text {th }}$ century, Kant's views on man and human nature are not so often cited. Meanwhile, human nature is one of the most important subjects in Kant's philosophy, reflections on which we find in many works of Kant. Certain anthropological remarks can easily be detected in Kant's early writings, for example, in Observations on the Feeling of the Beautiful and Sublime, where we find reflections on the characteristics of not just individuals, but also of people of different nationalities, different cultures and different sexes. Remarks of this kind also occur in subsequent years. Still, these observations belong to what we would call empirical anthropology. Though this frequent Kantian creativity is extremely entertaining, the focus for us will lie in what we would rather refer to as the foundations of Kantian anthropology, the fundamental provisions defining the Kantian view 
of man and the essential features of his nature. Such reflections we also find in abundance in the writings of Kant.

First of all, it is worth noting that the distinguished status of a person is fundamentally important for Kant. Kant gives man a special dignity. Already in the second Critique man appears as an end in itself. This fundamental view forms the basis of one of the categorical imperative formulations: "Act so that you use humanity, as much in your own person as in the person of every other, always at the same time as end and never merely as means" (GMS, AA 4, 429). ${ }^{1}$ We find a more detailed discussion of these issues in the Feyerabend's Natural Law Notes, a lecture course from the mid-80s of the $18^{\text {th }}$ century. Here Kant examines the concept of value in detail, emphasizing that all creatures of our world can have value, but the value they have is conditional, since it is measured by how much these creatures are valuable as a means to an end. The more they are useful in achieving some intended goal, the more valuable they are. But a human being has value in itself, regardless of ends, a means to which a human being can be. Consequently, the value that he possesses is unconditional. Moreover, it is derived from human freedom. In our world only human being is has freedom of will, and thanks to this he has unconditional value (V-NR/Feyerabend, AA 27, 1322-1323). ${ }^{2}$

Thus, by the time of the writing of the second Critique it can be stated that Kant had a distinctly formed view of man as a unique being, since only man can have dignity. Each person possesses it. Moreover, this characteristic is inalienable; it belongs to man insofar as he is a man, a special kind of living being. The final formulation of this view is found in the third Critique, where man is defined as the final end and as such, he cannot lose his dignity and cannot turn into just a means. The whole world is a combination of various interconnections, where different objects are alternately ends or means, and everything can be seen in certain contexts as an end, but in turn be a means to achieve a higher end. However, this is not possible for the end, which in itself is final. In principle, it cannot be a means to some higher end,

\footnotetext{
${ }^{1}$ Immanuel Kant, Groundwork of the Metaphysics of Morals, transl. Mary Gregor, Jens Timmermann (Cambridge: Cambridge University Press, 2011), 46-47.

${ }^{2}$ Immanuel Kant, "Natural right course lecture notes by Feyerabend", in: Lectures and Drafts on Political Philosophy, transl. Fred Rauscher (Cambridge: Cambridge University Press, 2018), 84-85.
} 
since there is simply no higher end. This is the human being who is this end (KU, AA 5, 435). ${ }^{3}$

But the third Critique is interesting for us, first of all, because here we find not only a statement of why a person is the ultimate end, but also an explanation of this fact. What exactly makes a person so strong? This specific property is morality. Here it is important to emphasize that this is due to the fact that only man is a moral being. In this way, Kant defines morality as the characteristic of a human being that distinguishes him from other beings. It is morality that distinguishes man from all other creatures of this world. Consequently, it is morality that man is called upon to develop. The more moral a person becomes, the more he thereby develops his humanity.

Of course, Kant achieves such a clear wording only in the third Critique. However, in previous works, Kant deals with the issue of morality, its importance for human beings and what it actually consists in. So, already in the first Critique, devoted mainly to the consideration of theoretical philosophical issues, we find a statement of the existence of practical laws, which commands with absolute necessity $(\mathrm{KrV}, \mathrm{AA} \mathrm{3}, 524) .{ }^{4}$ And here in the first Critique Kant arrives at a certain ideal model - a "system of self-rewarding morality", in which "freedom, partly moved and partly restricted by moral laws, would itself be the cause of the general happiness, and rational beings, under the guidance of such principles, would themselves be the authors of their own enduring welfare and at the same time that of others" (KrV, AA 3, 525). ${ }^{5}$ But such a system is possible only "in an intelligible world, i.e., in the moral world, in the concept of which we have abstracted from all hindrances to morality (of the inclinations)" (KrV, AA 3, 525). ${ }^{6}$ Creatures that are members of such a system would not violate the dictates of moral law. Their will is constantly, at every moment of their existence, would be in accordance with its commands. In future (in the Critique of Practical Reason and in the Religion

\footnotetext{
${ }^{3}$ Immanuel Kant, Critique of Judgment, transl. Werner Pluhar (Indianapolis, Cambridge: Hackett Publishing Company, 1987), 323.

${ }^{4}$ Immanuel Kant, Critique of Pure Reason, trans. and ed. Paul Guyer, Allen Wood (Cambridge: Cambridge University Press, 1998), 678.

${ }^{5}$ Kant, Critique of Pure Reason, 679.

${ }^{6}$ Ibidem.
} 
within the Boundaries of Mere Reason), this state will be called holiness and considered as unattainable for a person in flesh and blood.

Even being in a sensible world, a person does not lose his intelligible component. A human being simply faces a series of obstacles resulting from his sensitive nature. Thus, a person is a citizen of two worlds and as such is doomed to be in constant struggle, in the struggle for the fullest possible approximation to the implementation of the moral law, i.e. to holiness. Kant calls this struggle a virtue. It is virtue which is the destiny of man. Moreover, the fact that more often Kant speaks precisely of virtue rather than of holiness shows how his philosophy is focused on a real empirical human being, and not on an imaginary, abstract one. In essence, holiness falls into the sphere of Kant's consideration only to the extent of being a guideline, a regulatory idea, in pursuit of which a person achieves moral development.

The concept of holiness, as well as a more detailed examination of what constitutes virtue, is already found in the second Critique. Here (and in earlier Groundwork) Kant talks in more detail about how one should understand the moral law. Let us consider only the fact that in the Groundwork and in the second Critique Kantian conviction that following the moral law is a duty of human being is traced more clearly. Moreover, this obligation is absolutely necessary and is comprehended by each person a priori, regardless of individual characteristics and specific living conditions. In other words, each person must follow a moral law, i.e. each person should be virtuous, or each person should strive for holiness (not to achieve it, but to strive towards it, and this is the essence of virtue). To which extent each person corresponds to this duty is a different question. Yet it is precisely this obligation that Kant turns into the paramount task of the human being, as a creature endowed with practical reason.

This moral essence of man is emphasized in a special way in the third Critique, where Kant expressively states that it is precisely because of his moral nature that man is the final end of creation (KU, AA 5, 435). ${ }^{7}$ Here we can note that Kant's reflections on the nature of man acquire a rather communal character. He talks about man in general, in fact about the mankind as such. The mankind, represented by its individual representatives, is the ultimate

\footnotetext{
${ }^{7}$ Kant, Critique of Judgment, 323.
} 
end of nature, and humanity is called to moral development, to the development of its virtue, and, ultimately, to constant approximation to the ideal of holiness.

The communal element appears more distinctly in Kant's later work, Religion within the Boundaries of Mere Reason. Here Kant presents another ideal model - the model of an ethical community, i.e. a community built according to the laws of virtue (ethical laws) (RGV, AA 6, 98-99). ${ }^{8}$ Kant also calls this ethical community the ethico-civil society as opposed to a juridico-civil one, i.e. the one where people obey juridical laws based on external coercion $(\mathrm{RGV}, \mathrm{AA} 6,94)^{9}$ rather than ethical laws. However, Kant emphasizes that such a community can only be universal, i.e. it is possible for it to be ethical only if all representatives of the mankind voluntarily enter it. Only in this case does it have a chance to succeed. Otherwise, "human beings (as we remarked above) mutually corrupt one another's moral predisposition and, even with the good will of each individual, because of the lack of a principle which unites them, they deviate through their dissensions from the common goal of goodness, as though they were instruments of evil, and expose one another to the danger of falling once again under its dominion" (RGV, AA 6,97$).{ }^{10}$ In fact, such a community is an analogue of the "system of selfrewarding morality" presented in the first Critique, which, as such, is realizable only if it is universal. Still, unlike the first Critique, here Kant clearly defines that the establishment of such a community is not just a goal and task of all mankind, but is also its duty (RGV, AA 6, 94) ${ }^{11}$ Although it is for the first time that Kant expresses himself so sharply, we should not view this new duty as a radical turn in the philosophy of Kant, as it represents simply a new formulation of the duty to promote the realization of the highest good by all means, which was already well-known since the second Critique. ${ }^{12}$ Just as

${ }^{8}$ Immanuel Kant, Religion within the Boundaries of Mere Reason, transl. Allen Wood, George di Giovanni (Cambridge: Cambridge University Press, 1998), 109.

${ }^{9}$ Kant, Religion, 106.

${ }^{10}$ Ibidem, 108.

${ }^{11}$ Ibidem, 106.

${ }^{12}$ Habichler supposes that in the Religionsschrift the Kantian idea of the kingdom of God (or ethical community) reaches its maturity (Alfred Habichler, Reich Gottes als Thema des Denkens bei Kant. Entwicklungsgeschichtliche und systematische Studie zur kantischen ReichGottes-Idee (Mainz: Matthias-Grünewald-Verlag, 1991), 224). At the same time, Habichler 
in previous works, where the duty of promoting the highest good ultimately led us to postulate the existence of God, in this writing Kant inevitably comes to the conclusion that an ethical community is conceivable only as a people guided by divine commandments, as a people of God, and, moreover, according to the laws of virtue (RGV, AA 6, 100). ${ }^{13}$ It is God and only He alone who can be the legislator in this type of community, since, on the one hand, only his laws are perceived by us as commandments and, on the other hand, only he is able to see the true motives of people's actions and thus to evaluate not only the external conformity of the act to the moral law, but also the morality of the individual (RGV, AA 6, 99-100). ${ }^{14}$

In this case the sphere of internal motives, or the disposition (Gesinnung), is important for Kant. It is here that Kant seeks and finds an explanation for the man's unkind actions arising from radical evil, the man's tendency to give preference to sensible (satisfying needs), and not intelligent (obedience to duty) motives of behaviour. Holiness is now determined by Kant through an appeal to the sphere of disposition. Holiness is nothing more than "the recovery of the purity of the law, as the supreme ground of all our maxims, according to which the law itself is to be incorporated into the power of choice, not merely bound to other incentives, nor indeed subordinated to them (to inclinations) as conditions, but rather in its full purity, as the self-sufficient incentive of that power" (RGV, AA 6,46$).{ }^{15}$ Thus, the goal and duty of man and mankind is the desire for the maximum possible purification of their maxims, up to their complete coincidence with the commands of the moral law, i.e. for holiness.

However, the question of the human nature formulated in this way, as well as the answer given by Kant redirects us to the issue of human destiny, very popular in the Enlightenment in Germany. The reason for starting the discussion on this subject is J.J. Spalding, philosopher well-known in Germany in the second half of the $18^{\text {th }}$ century, and his work The Destiny of Man, first published in 1748 .

considers this idea not to be just a derivation from the idea of the highest good, but the very idea of the highest good, presented there in a slightly modified form (op. cit., 191-194, 218).

${ }^{13}$ Kant, Religion, 110.

${ }^{14}$ Ibidem, 109-110.

${ }^{15}$ Ibidem, 67. 


\section{Johann Joachim Spalding on the Destiny of Man}

J.J. Spalding is a well-known thinker, philosopher and theologian, a preacher, contemporary of Kant. He died in the same year as Kant, although the beginning and heyday of his creative activity came at an earlier time than the beginning of Kant's academic activity. Recently, more and more studies have been devoted to the work of Spalding, where he is seen not only in the capacity of a forerunner to the subsequent more famous thinkers, such as Mendelssohn, Kant, Goethe, Herder and especially Schleiermacher and others, but also as an independent philosopher and theologian. ${ }^{16}$ They focus on the theological views of Spalding - his understanding of Christianity and his version of theological anthropology, expressed in musings on the purpose and meaning of man's earthly existence and on the relation in which man stands to God. Yet, his theological views are in fact extremely difficult to distinguish from his philosophical ones.

${ }^{16}$ The first researchers to pay close attention to the enormous importance of Spalding for the entire German Enlightenment were J. Schollmeier and N. Hinske: Josef Schollmeier, Johann Joachim Spalding. Ein Beitrag zur Theologie der Aufklärung (Gütersloh: Gütersloher Verlagshaus, 1967); Die Bestimmung des Menschen, ed. Norbert Hinske (Hamburg: Felix Meiner Verlag, 1999). A special merit in changing the direction of the interpretation of Spalding belongs to A. Beutel: Albrecht Beutel, "Johann Joachim Spalding. Populartheologie und Kirchenreform im Zeitalter der Aufklärung”, in: Theologen des 17. und 18. Jahrhunderts: konfessionelles Zeitalter, Pietismus, Aufklärung, ed. Peter Walter, Martin Jung (Darmstadt: Wissenschaftliche Buchgesellschaft, 2003), 226-243; Albrecht Beutel, “Aufklärung des Geistes. Beobachtungen zu Spaldings Pfingstpredigt 'Der Glaube an Jesum, als das Mittel zur Seeligkeit", in: Christentum im Übergang. Neue Studien zu Kirche und Religion in der Aufklärungszeit, ed. Albrecht Beutel, Volker Leppin, Udo Sträter (Leipzig: Evangelische Verlagsanstalt, 2006), 119-128; Albrecht Beutel, Aufklärung in Deutschland (Göttingen: Vandenhoeck \& Ruprecht, 2006). In addition, mention should also be made of such works as: Caroline Tippmann, Die Bestimmung des Menschen bei Johann Joachim Spalding (Leipzig: Evangelische Verlagsanstalt, 2011); Georg Raatz, Aufklärung als Selbstdeutung. Johann Joachim Spaldings "Bestimmung des Menschen" (1748): eine genetisch-systematische Rekonstruktion (Tübingen: Mohr Siebeck, 2014); Laura Anna Macor, "Die Abhängigkeit des Menschen von Gott. Zur Endlichkeit als Geschöpflichkeit bei Johann Joachim Spalding”, in: Endlichkeit und Transzendenz. Perspektiven einer Grundbeziehung, ed. Jakub Sirovátka (Hamburg: Felix Meiner Verlag, 2012), 124-131; Laura Anna Macor, Die Bestimmung des Menschen (1748-1800). Eine Begriffsgeschichte (Stuttgart-Bad Cannstatt: Frommann-Holzboog, 2013). 
Spalding belonged to the so called movement of neologists, who saw their main task in the purification of Christianity, the presentation of a new Christian teaching, which turned out to be the ancient one, i.e. the true teaching of Christ, in contrast to the superficial, scholastic representation that can be found both in Catholicism as well as in Lutheran orthodoxy. As a result, neologists came to denying many of the fundamental Christian dogmas, or at least to recognizing the mas insignificant for the salvation of the soul. As a moderate neologist, Spalding questioned only two of these basic Christian truths-the doctrine of predestination and of the original sin. Other dogmas were not questioned, although they were excluded from the list of necessary ones. In any case, Spalding's view of things diverged greatly from the Lutheran orthodoxy, which caused a flurry of general criticism of him, which followed immediately after the publication of The Destiny of Man.

The Destiny of Man is a programmatic writing for Spalding, since it reflects (in a condensed form) all the ideas that Spalding will develop in more detail in his subsequent works and reprints of The Destiny of Man. For this reason, we limit ourselves to mainly discussing this work. Another reason for considering this specific work is the great importance that it had for the entire German Enlightenment. It was this writing that had the greatest resonance among German and foreign enlighteners and became fundamental for the formation of one of the most important themes of the Late Enlightenment in Germany, namely the question of the purpose of the existence of man and humanity.

The main question that Spalding poses at the very beginning of his writing is: "... why am I here and what should I be in accordance with my mind"? ${ }^{17}$ Being so formulated, it opens up a wide scope of issues for consideration on the true purpose of human life, as well as possible ways to achieve it. In fact, the author directs his efforts towards the search for the most correct and appropriate way of life for a person.

Several possibilities of living on the earth of the time allotted to us are being successively dealt with. The first and most obvious way - life in a constant

${ }^{17}$ Johann Joachim Spalding, Die Betrachtung über die Bestimmung des Menschen (Greifswald, 1748), 3. This question runs through the whole work of Spalding. It is formulated equally distinctly in his later writings, especially in Ueber die Nutzbarkeit des Predigtamtes und deren Beförderung (1772) and Religion, eine Angelegenheit des Menschen (1797). 
pursuit of ever new sensual pleasures - is quickly discarded in view of its complete failure and unsuitability. ${ }^{18}$ The second possible way - concentrating on the development of the spirit and the abilities embedded in it - can, however, fill the soul with that favour which it lacks in sensual pleasures alone. Yet, such a path, which encourages the person to concentrate ultimately on oneself, although is far preferable to diving in sensual pleasures alone, is still not what we are called to. ${ }^{19}$ Spalding discovers another kind of pleasure, as innate and natural as the pleasure of feelings, namely, the pleasure of doing good work for another person. This pleasure obviously has nothing to do with aspirations for one's own benefit and well-being, and must come from a completely different source, which, according to Spalding, is the notions that are right and that befit a person as a free rational being, which were originally laid in the soul. In the world around us, we observe a rational order and harmony. In fact, our only task is not to violate these relations between the things of the world that exist beside us, but rather, to try by all means to strengthen the agreement between them. ${ }^{20}$

But who is the creator of this primordial and universal order? Here Spalding goes on to think about God, about the creator of all things, about the prototype of perfection. Compared to him, each person is insignificant, and only his ability to feel and ascend to the origins of this predetermined divine order in the surrounding world makes him something. This is the ability to know God. It is to such knowledge that man is called, and it is this knowledge that is the ultimate goal of the soul. However, such an ascent is possible only for a righteous soul, living in accordance with moral standards. Only in this way can the soul win the favour of God, in whose hands are all destinies. ${ }^{21}$ The hope of a person for happiness is also rooted in him, because if a person does not make himself unworthy of divine favour and care with his immoral actions, then who can harm him? However, due to the fact that here, on earth, in our daily life, we do see no special care from the creator for righteous souls, we naturally come to the conclusion that the soul is called to eternal life and

\footnotetext{
${ }^{18}$ Spalding, Betrachtung, 4-7.

${ }^{19}$ Ibidem, 7-8.

${ }^{20}$ Ibidem, 8-14.

${ }^{21}$ Ibidem, 15-18.
} 
after death, in afterlife, the soul will receive a just retribution for all its earthly affairs. ${ }^{22}$

It is worth drawing attention to some features of this work. First of all, there was a verified turn from the consideration of mainly theoretical-cognitive issues to the questions of a person's practical activity. On the other hand, it is human morality that stands out from all practical activity. It is morality which is, according to Spalding, the hallmark of a human being. Virtue is that which is found only in a human being. This is a specific trait of man that distinguishes him from all living beings. And consequently, it is exactly to the development of this specific ability that man is called. Throughout his life Spalding consistently held the view that the highest goal of human life, his destiny cannot be found in the pleasures of outer life. ${ }^{23}$ It can only be seen when referring to its inner sphere. ${ }^{24}$ This purpose is the pursuit of a virtuous lifestyle.

It is also important to note that, for Spalding, like for Kant, the recognition of virtue for the destiny of man is a road to religion. We are called to be virtuous. Another feature, also common to all people, is the desire for happiness. In order to obtain hope for the possibility of combining these two fundamental aspirations of human nature, we need to assume the existence of God and the immortality of the soul. This idea runs through all writings of Spalding devoted to this problem. At the same time, we have reason to assume the influence exerted by Spalding on the formation of Kantian views. Firstly, for Spalding, as later for Kant, the fact of the presence of two equal motives in a person is clearly emphasized - the desire to be worthy of happiness (virtue) and the desire for happiness itself. Secondly, Spalding also notes the problematic nature of their combination: on earth, we do not see a just retribution for righteousness to the righteous and for sin and vice to the sinners. Thirdly, like Kant in his Critique of Pure Reason, Spalding as early as 1748 on the basis of this discrepancy between happiness and dignity to be happy derives the need for a person to assume the afterlife and God as a legislator in it, which will make possible proportional harmonious combination

\footnotetext{
${ }^{22}$ Ibidem, 18-23.

${ }^{23}$ Johann Joachim Spalding, Religion, eine Angelegenheit des Menschen (Leipzig, 1806), 9.

${ }^{24}$ Spalding, Religion, 9, 23, 187.
} 
of two components, if not in this world, then at least in another world after death. Thus, the very first edition of The Destiny of Man, in general terms, reminds us of the Critique of Pure Reason and the version of the postulation of the immortality of the soul and the existence of God present there.

The influence of Spalding becomes even more likely when considering his other writing, Confidence Letters on Religion (1784), where Spalding examines in detail the question of how morality leads to religion. At the same time, the issue of whether moral atheists are possible is already emerging here. It is interesting to note that the fragment examining the question of whether a moral atheist is possible is close to the example of the righteous man, Spinoza, from the third Critique of Kant (KU, AA 5, 452). ${ }^{25}$ Like in Kant, Spinoza is given as an example of a righteous person. And like Kant, Spalding concludes that in theory, nothing prevents us from suggesting that such a righteous atheist is possible, since morality does not depend on religion, on belief in rewards or punishment in afterlife. However, in practice this does not occur, since a genuine moral attitude inevitably drives us to believe in God. ${ }^{26}$

At the same time, it should be noted that there was also the opposite effect - the influence of Kant on Spalding, which can be clearly seen in the later work of Spalding Religion, the work of man (1797). Spalding does not doubt that there is something that interests and is equally important for every person. In order to justify that that is precisely religion Spalding wrote this writing. ${ }^{27}$ Moreover, this justification, as in his other works, is built on the basis of the allocation of the two essential aspirations of human nature - the desire for well-being ${ }^{28}$ and the inner moral sense of right and wrong, fair and unjust. ${ }^{29}$ From the combination of these two components the highest goal is formed, to the realization of which we are called by our rational nature.

Religion provides us with invaluable assistance with respect to each of these components. For morality, religion, understood as "recognition of the

\footnotetext{
${ }^{25}$ Kant, Critique of Judgment, 341.

${ }^{26}$ Johann Joachim Spalding, Vertraute Briefe, die Religion betreffend (Breslau, 1785), 44-47.

${ }^{27}$ Spalding, Religion, 5 .

${ }^{28}$ Ibidem, 10-11.

${ }^{29}$ Ibidem, 14, 132, 256, 259.
} 
all-perfect ruler of the world in his relation to us", ${ }^{30}$ is a strong support and help. The thought that it is the highest being, which sees us, and the imitation of the holiness for which we should strive, ${ }^{31}$ gives us strength in our fight against vices and sins, ${ }^{32}$ influencing our soul and giving our moral sense great power. ${ }^{33}$ A man, deprived of faith in the existence of God, deprives himself of this advantage. ${ }^{34}$ But with respect to the second component - the pursuit of happiness - religion is no less useful for us, since ultimately only faith in a good, fair and omnipotent world ruler can give us comfort, hope and even confidence in the achievement of happiness by a righteous person. ${ }^{35}$

Thus, the religious way of thinking gives moral feelings a great effective force, and the desire for happiness a great confidence ${ }^{36}$. It is faith in God as such a creature that, on the one hand, requires virtuous behaviour from us, and on the other hand, wants our happiness and is able to give it to us, that Spalding considered a true religiosity.

At the same time, it would be wrong to believe that morality is derived by Spalding from faith in God, which would mean in fact the impossibility of morality without religion. On the contrary, exactly like Kant, Spalding emphasizes that virtue cannot depend on fear of God's punishment or the hope of God's retribution, for in this case it would not be virtue: "The moral law is given in our minds independently and speaks to us directly whether we owe something or do not" ${ }^{37}$ However, faith in a wise creator and ruler of the world does not deprive virtue of its essence and dignity. ${ }^{38}$ On the contrary, such a faith is a testament to the true virtue of a person, since any righteous person will strive to use all possible means that strengthen him in his righteousness, and religion is such a means. ${ }^{39}$

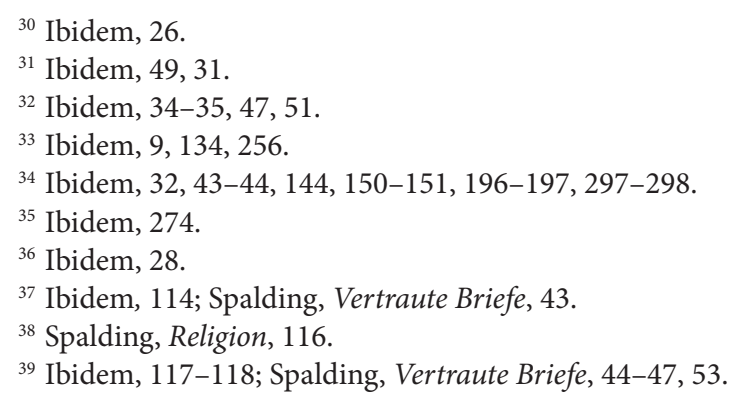


Summing up, we can say that Spalding and Kant have a lot in common. Both of them thought about the destiny of man. Both saw it in the morality of a human being. Both moved from morality to the need for religion. Both equally emphasized that religion cannot and should not be the foundation of morality, otherwise it would lead to the loss of genuine virtue through the introduction of heteronomic motives of reward or punishment in the process of determining the will to act. Such a comparison shows, on the one hand, how Kant was rooted in the philosophy of the German Enlightenment, and, on the other hand, it also shows us how Kant himself influenced the enlighteners, already during his lifetime and even those more famous than Kant himself.

\section{Moral Philosophy of Christian Wolff and the Early Enlightenment Roots of the Kantian Point of View}

In order to assess the significance of this issue for the German Enlightenment in its entirety it would not be superfluous to turn to the philosophy of the Early German Enlightenment, namely, to the philosophical views of Christian Wolff. The choice of this thinker in the context of our topic is not accidental. Although among his treatises we will not find separate writings containing the phrase "the purpose of man" or similar, nevertheless his view on the essence of human being, as well as on the purpose of life due to this essence, can be considered clearly articulated. In addition, Wolff is often considered the founder of atheistic morality. It is difficult to completely agree with this point, but this research position has a definite basis, as evidenced by the comparison of Wolff's philosophy with Spinozism, developed in the $18^{\text {th }}$ century, especially in its first half, which for that time was essentially similar to comparing it with atheism. Indeed, in Wolff's philosophy we see an attempt to find the foundation of morality in the nature of man and the world rather than in the all-good will of God. Subsequently, Kant set similar goals for himself. Let us consider in more detail the basis of the moral philosophy of Wolff.

Wolff formulates the basic principles of his ethical system in his work German Ethics, which was first published back in 1720 . The main subject of 
consideration in Wolff's philosophy was "the good of the human race". ${ }^{40}$ Ultimately, it was in search of ways to achieve the latter that all efforts of the thinker were directed. Wolff defines Good in an extremely simple way as something that "makes us more perfect", ${ }^{41}$ or "improves us and our conditions"; ${ }^{42}$ the opposite of good, evil, is what makes us and our states less perfect. ${ }^{43}$ Perfection, therefore, turns out to be the main and, by and large, the only criterion for evaluating the moral component of things and human actions: any of our actions that contribute to increasing perfection in the world are good, while actions that contribute to reducing perfection, on the contrary, are evil in nature. ${ }^{44}$ Basing on this, Wolff formulates the basic rule for his practical philosophy, which he calls a natural law or a law of nature: "Do what makes you and yours or someone else's state more perfect; avoid making it less perfect". ${ }^{45}$

At the same time, Wolff himself gives somewhat differing definitions of perfection. The fact that Wolff does not simply describe perfection as a static ideal state that either does or does not exist in a thing, but rather speaks of different degrees of perfection and so considers also the dynamic aspect, remains indisputable. For us, progress in perfection understood as orientation toward its gradual increase both in ourselves and in other people and in the whole world is possible. In fact, only this never-ending, eternal process of ever closer approaching the maximum degree of perfection can be our destiny, since the highest perfection is available only to God and not one of his creations is able to achieve it. ${ }^{46}$ Thus, according to Wolff, it is precisely the increase in the level of perfection in the world (to the extent possible for us) that should be the main goal (Hauptabsicht) of our whole life. All other, private, goals, both by themselves, individually, and all together in their totality, must serve as means to achieve it ${ }^{47}$.

${ }^{40}$ Christian Wolff, Vernünftige Gedanken von Gott, der Welt und der Seele des Menschen, auch allen Dingen überhaupt (Halle, 1747), [2].

${ }^{41}$ Christian Wolff, Vernünfftige Gedancken von der Menschen Thun und Lassen, zu Beförderung ihrer Glückseeligkeit (Halle, 1743), 6.

${ }^{42}$ Wolff, Vernünftige Gedanken von Gott, der Welt und der Seele des Menschen, 260.

${ }^{43}$ Wolff, Vernünffige Gedancken von der Menschen Thun und Lassen, 6.

${ }^{44}$ Ibidem, 6-7.

${ }^{45}$ Ibidem, 12.

${ }^{46}$ Ibidem, 31.

${ }^{47}$ Ibidem, 29-30, 79-80, 84-85. 
We see that Wolff's moral philosophy in its foundations is not directly related to God and his will, which gives reason for some researchers to see him as the founder of a theonomic ethics. ${ }^{48}$ However, upon closer examination, as in the case of Kant, the relationship of morality and religion in Wolff's view is not that unambiguous. In order to understand this, it is enough to take a careful look at his other work, "Speech on the Practical Philosophy of the Chinese" (1721), which provoked fierce criticism and accusations of atheism, resulting in Wolff's expulsion from Halle.

When comparing it with other Wolff's works written earlier, we cannot find anything fundamentally new here. The terms, the main conclusions and the methods of argumentation in the Speech are fully consistent with the Latin Universal Practical Philosophy (1703) as well as the German Ethics (1720). The criterion of good in the Speech as well as in other works on moral philosophy is perfection. ${ }^{49}$ Everything that contributes to the change in our condition, making it more perfect, is good. On the contrary, whatever makes us less perfect is evil. ${ }^{50}$ It is natural for the soul to choose the good, just as it is natural for it to avoid the evil. ${ }^{51}$ That is why Wolff also claims that the highest moral rule should be in following the law of the nature of the human spirit. ${ }^{52}$ If the soul chooses evil, it is only because it is in error, mistaking evil for good. ${ }^{53}$ Therefore, learning is important, and in the process a person comprehends

${ }^{48}$ Michael Albrecht, "Einleitung”, in: Christian Wolff, Rede über die praktische Philosophie der Chinesen, ed. Michael Albrecht (Hamburg: Felix Meiner Verlag, 1985), XXXVI; Heiner Klemme, "Der Grund der Verbindlichkeit. Mendelssohn und Kant über Evidenz in der Moralphilosophie (1762/64)”, Kant-Studien, 109 (2) (2018), 295-296; Werner Schneiders, Aufklärung und Vorurteilskritik. Studien zur Geschichte der Vorurteilstheorie (Stuttgart-Bad Cannstatt: Frommann-Holzboog, 1983), 158.

${ }^{49}$ Many researchers rightly consider perfection to be a fundamental concept of Wolff's practical philosophy (Anton Bissinger, "Zur metaphysischen Begründung der Wolffschen Ethik", in: Christian Wolff 1679-1754. Interpretationen zu seiner Philosophie und deren Wirkung. Mit einer Bibliographie der Wolff-Literatur, ed. Werner Schneiders (Hamburg: Felix Meiner Verlag, 1986), 156; Heinrich Böckerstette, Aporien der Freiheit und ihre Aufklärung durch Kant (Stuttgart-Bad Cannstatt: Frommann-Holzboog, 1982), 109, 111; Tommaso Opocher, Christian Wolff. Filosofo del diritto e della politica (Milani: CEDAM, 2013), 62, 64.

${ }^{50}$ Christian Wolff, Rede über die praktische Philosophie der Chinesen, ed. Michael Albrecht (Hamburg: Felix Meiner Verlag, 1985), 51, 31-33.

${ }^{51}$ Ibidem, 31.

${ }^{52}$ Ibidem, 25.

${ }^{53}$ Ibidem, 31. 
the nature of things and becomes able to avoid delusions about the goodness or malice of their nature. ${ }^{54}$ This was perfectly understood by the Confucians, who have created a brilliant system of education, aimed not at comprehension of high theoretical truths abstracted from real life, but at the study of the nature of things, subordinated in turn to the only highest goal - to achieve happiness. ${ }^{55}$ The highest good possible for man is constant progress towards ever greater perfection. The fact that Confucius understood this and called for it both in his teaching and by personal example, ${ }^{56}$ also meets the ardent praise of Wolff, matching his own views on this subject. ${ }^{57}$

As a result, with the example of the Chinese in this writing, Wolff concisely, but very consistently pursues the idea that the natural forces of man are enough ${ }^{58}$ to achieve virtue, which is constant focusing on improvement. This is primarily possible because to achieve virtue it is necessary to constantly strive to choose good, and this in itself is embedded in the nature of the human soul. In order to make the right choice and not get mistaken, the soul needs to have knowledge of the essence of things, but knowledge realized by reason is also a natural ability of the soul. And the will, allowing a person to pursue the good he or she recognized, is also a natural ability of the soul. Thus, a person by nature possesses everything necessary for virtuous behaviour, and it is enough to act in accordance with the nature of the human spirit, without waiting for help from God. This is precisely what caused Wolff's accusations of atheism, as well as the later vision of him as one of the first founders of a theonomic morality.

However, these conclusions regarding Wolf's philosophy are far from unambiguous. Even at the beginning of the "Speech", Wolff stipulated that virtue can be of three kinds: 1) virtue, achieved only through natural forces; 2) virtue achieved through the intelligent comprehension of the attributes of God (i.e., natural religion); 3) virtue achieved with the help of divine guidance, through the truths revealed in Revelation (i.e. the religion of Revelation). ${ }^{59}$

\footnotetext{
${ }^{54}$ Ibidem, 45-47.

${ }^{55}$ Ibidem, 43.

${ }^{56}$ Ibidem, 185-187, 215.

${ }^{57}$ Ibidem, 57.

${ }^{58}$ Ibidem, 33.

${ }^{59}$ Ibidem, 27.
} 
The first is called by Wolff a philosophical virtue, the second - a philosophical piety, the third - a theological or Christian virtue.$^{60}$ It is not difficult to see that in Wolff's opinion only the virtue of the first kind, i.e. the lowest level of virtue, can be achieved by the Chinese. Neither the third, nor even the second are accessible to the Chinese precisely because they have no faith in the true God. Only the virtue of the third kind brings man as close as possible to the desired perfection, although even it does not allow him to achieve it fully.

Why is this so? In his "German Ethics", Wolff distinguishes between "childlike fear" and "slavish fear" of God. "Slavish fear" is a fear of divine punishment that follows evil deeds. ${ }^{61}$ This kind of fear of God does not bring, but only distances a person from true virtue. The Chinese, who have no idea of God, in principle cannot have this kind of fear. It is from this point of view that Wolff praises (and very highly) the Chinese worldview and Chinese moral philosophy. Still, childlike fear is completely different. Not only does it not hinder achieving virtue, but on the contrary contributes to it. It is a "thoroughness in actions and omissions, so as not to do what is contrary to God, or not to miss what he wants" 62 and is directly related to the love of God. ${ }^{63}$ What we do out of love, we do willingly. In case of commitment of willing acts it makes no sense to talk about coercion and restriction of our freedom. ${ }^{64}$ Since God does not command us and does not want anything that would be contrary to the natural law, then the will of God is identical with the natural law, and a person who has fear of God and does good out of love for Him will be in accordance with the provisions of the natural law, i.e. advancing along the path of improvement. Love for God and the fear directly related to it of offending Him with one's actions not only do not harm virtue, but conversely are its most complete expression. ${ }^{65}$ It was in the inaccessibility of the latter for the Chinese that Wolff saw their misfortune that made it impossible for them to achieve the highest degree of perfection available to a human being.

\footnotetext{
${ }^{60}$ Ibidem, 139.

${ }^{61}$ Wolff, Vernünfftige Gedancken von der Menschen Thun und Lassen, 482-483.

${ }^{62}$ Ibidem, 478.

${ }^{63}$ Ibidem, 478-479.

${ }^{64}$ Wolff, Vernünftige Gedanken von Gott, der Welt und der Seele des Menschen, 608.

${ }^{65}$ Wolff, Vernünffige Gedancken von der Menschen Thun und Lassen, 30-31.
} 


\section{Conclusion}

Thus, we see that already at the very beginning of the German Enlightenment, in the philosophy of Wolff, who was often accused of atheism, the same motives can be traced that would be then characteristic for Spalding and Kant. First, all three philosophers saw the essential feature of human being in his moral dimension, in his virtue. It was in its development that they saw the destiny of human being, the ultimate goal of his existence. Secondly, they all tried to justify morality not with the will of God expressed directly in the Sacred Scripture, but with grounds of reason, which resulted in deriving the basic principle of morality from human nature. Thirdly, such a justification of morality creates the illusion of the complete independence of ethics from faith in God. This seems to be especially evident in Kant's philosophy, since in all his main works he stressed that morality does not depend on religion. However, such a statement, upon closer examination, is shattered, since morality, while not depending on religion, inevitably leads to it. Faith in God turns out to be an integral part of a true moral attitude. We can in theory imagine a man who is virtuous and does not believe in God, but in practice it is impossible to meet him or her. The comparison of this position of Kantian practical philosophy with the views of another thinker of his time, I.I. Spalding, allows us to conclude that in this case Kant is not innovating but rather expressing a quite common trait of his time. The comparison of Kantian philosophy with the philosophy of Chr. Wolff convinces us that this position is common not only for the Late Enlightenment, but goes back to the thinkers of the Early Enlightenment. The only significant difference is that while the thinkers of the Early Enlightenment understood the true faith in God as Lutheranism exclusively, the thinkers of the Late Enlightenment more and more departed from this position, and by faith in God they understood different forms of natural religion. This was most clearly manifested in the Kantian project of the moral religion of reason. 


\section{References}

Albrecht Michael. 1985. “Einleitung”. In: Wolff Christian. Rede über die praktische Philosophie der Chinesen. Ed. Michael Albrecht. IX-LXXXVIII. Hamburg: Felix Meiner Verlag.

Beutel Albrecht. 2003. "Johann Joachim Spalding. Populartheologie und Kirchenreform im Zeitalter der Aufklärung”. In: Theologen des 17. und 18. Jahrhunderts: konfessionelles Zeitalter, Pietismus, Aufklärung. Ed. Peter Walter, Martin Jung. Darmstadt: Wissenschaftliche Buchgesellschaft.

Beutel Albrecht. 2006. "Aufklärung des Geistes. Beobachtungen zu Spaldings Pfingstpredigt 'Der Glaube an Jesum, als das Mittel zur Seeligkeit”. In: Christentum im Übergang. Neue Studien zu Kirche und Religion in der Aufklärungszeit. Ed. Albrecht Beutel, Volker Leppin, Udo Sträter. Leipzig: Evangelische Verlagsanstalt.

Beutel Albrecht. 2006. Aufklärung in Deutschland. Göttingen: Vandenhoeck \& Ruprecht.

Bissinger Anton. 1986. "Zur metaphysischen Begründung der Wolffschen Ethik". In: Christian Wolff 1679-1754. Interpretationen zu seiner Philosophie und deren Wirkung. Mit einer Bibliographie der Wolff-Literatur. Ed. Werner Schneiders. 148-160. Hamburg: Felix Meiner Verlag.

Böckerstette Heinrich. 1982. Aporien der Freiheit und ihre Aufklärung durch Kant. Stuttgart-Bad Cannstatt: Frommann-Holzboog.

Habichler Alfred. 1991. Reich Gottes als Thema des Denkens bei Kant. Entwicklungsgeschichtliche und systematische Studie zur kantischen Reich-Gottes-Idee. Mainz: Matthias-Grünewald-Verlag.

Kant Immanuel. 1987. Critique of Judgment. Trans. Werner Pluhar. Indianapolis, Cambridge: Hackett Publishing Company.

Kant Immanuel. 1998. Critique of Pure Reason. Trans. and ed. Paul Guyer, Allen Wood. Cambridge: Cambridge University Press.

Kant Immanuel. 1998. Religion within the Boundaries of Mere Reason. Transl. Allen Wood, George di Giovanni. Cambridge: Cambridge University Press.

Kant Immanuel. 2011. Groundwork of the Metaphysics of Morals. Transl. Mary Gregor, Jens Timmermann. Cambridge: Cambridge University Press.

Kant Immanuel. 2018. "Natural right course lecture notes by Feyerabend”. In: Lectures and Drafts on Political Philosophy. Transl. Fred Rauscher. 73-180. Cambridge: Cambridge University Press.

Klemme Heiner. 2018. "Der Grund der Verbindlichkeit. Mendelssohn und Kant über Evidenz in der Moralphilosophie (1762/64)”. Kant-Studien 109, 2: 286-308.

Macor Laura Anna. 2012. "Die Abhängigkeit des Menschen von Gott. Zur Endlichkeit als Geschöpflichkeit bei Johann Joachim Spalding”. In: Endlichkeit und Tran- 
szendenz. Perspektiven einer Grundbeziehung. Ed. Jakub Sirovátka. Hamburg: Felix Meiner Verlag.

Macor Laura Anna. 2013. Die Bestimmung des Menschen (1748-1800). Eine Begriffsgeschichte. Stuttgart-Bad Cannstatt: Frommann-Holzboog.

Opocher Tommaso. 2013. Christian Wolff. Filosofo del diritto e della politica. Milani: CEDAM.

Raatz Georg. 2014. Aufklärung als Selbstdeutung. Johann Joachim Spaldings "Bestimmung des Menschen" (1748): eine genetisch-systematische Rekonstruktion. Tübingen: Mohr Siebeck.

Schneiders Werner. 1983. Aufklärung und Vorurteilskritik. Studien zur Geschichte der Vorurteilstheorie. Stuttgart-Bad Cannstatt: Frommann-Holzboog.

Schollmeier Josef. 1967. Johann Joachim Spalding. Ein Beitrag zur Theologie der Aufklärung. Gütersloh: Gütersloher Verlagshaus.

Spalding Johann Joachim. 1748. Die Betrachtung über die Bestimmung des Menschen. Greifswald: Struck.

Spalding Johann Joachim. 1785. Vertraute Briefe, die Religion betreffend. Breslau: Gottlieb Löwe.

Spalding Johann Joachim. 1806. Religion, eine Angelegenheit des Menschen. Berlin: Voss.

Tippmann Caroline. 2011. Die Bestimmung des Menschen bei Johann Joachim Spalding. Leipzig: Evangelische Verlagsanstalt.

Wolff Christian. 1743. Vernünfftige Gedancken von der Menschen Thun und Lassen, zu Beförderung ihrer Glückseeligkeit. Halle: Renger.

Wolff Christian. 1747. Vernünftige Gedanken von Gott, der Welt und der Seele des Menschen, auch allen Dingen überhaupt. Halle: Renger.

Wolff Christian. 1985. Rede über die praktische Philosophie der Chinesen. Ed. Michael Albrecht. Hamburg: Felix Meiner.

\begin{abstract}
The paper concerns the issue of destination of human being and humanity in the philosophy of Kant and in the philosophy of German Enlightenment in general. In the philosophy of Kant the problem of destination of man runs throughout all his main writings from the pre-critical writings until the later work Religionsschrift. Kant pointed out that a human is a unique kind of being because of freedom of will, which allows for the moral dimension. It is this capacity of morality that becomes a bridge to religion. Very close to this point of view was J.J. Spalding, whose writing "The Destiny of Man" opened the discussion of the issue of man's destination. Similar ideas, though differently expressed, we find in the works of Christian Wolff,
\end{abstract}


a philosopher of Early German Enlightenment. Like Kant and Spalding, he assumed that although morality does not depend on the will of God and thus can be derived from the nature of man and the world, the highest and most genuine degree of virtue, possible for a human being, inevitably leads to faith in God. It can be concluded that in these aspects of his philosophy Kant reflected the trend and features which were characteristic for the Age of German Enlightenment both Late as well as Early.

Keywords: Kant, Wolff, Spalding, morality, religion, human being, man, mankind, destiny. 